\title{
СТРОЕНИЕ ВЕРХНЕЙ КОРЫ ЕЛЕЦКОГО УЧАСТКА ЛОСЕВСКОГО ТЕРРЕЙНА (ВОРОНЕЖСКИЙ КРИСТАЛЛИЧЕСКИЙ МАССИВ) ПО ДАННЫМ ПЛОТНОСТНОГО МОДЕЛИРОВАНИЯ
}

\author{
В. Н. Глазнев ${ }^{1,2}$, В. И. Жаворонкин ${ }^{1}$, О. М. Муравина ${ }^{1}$, И. Ю. Антонова ${ }^{1}$, \\ Т. А. Воронова ${ }^{1}$, А. В. Черешинский ${ }^{1}$, П. В. Холин ${ }^{1}$ \\ ${ }^{1}$ Воронежский государственный университет \\ ${ }^{2}$ Геологический институт КНЦ РАН, г. Апатиты
}

Поступила в редакцию 29 июля 2019 г.

\begin{abstract}
Аннотация: в работе рассматриваются методы и результаты геофизического изучения строения верхней коры Елецккого участка (северо-восток Воронежского кристаллического массива) по комплексу геолого-геофизических данных. Детальная трёхмерная плотностная модель была построена на основе инверсии локальных аномалий гравитационного поля в значения аномальной плотности относительно региональной плотностной модели литосферы Восточно-Европейской платформыл. В процедуре инверсии использовались данные о плотности комплексов пород кристаллического фундамента и оценочныле данные о мощности этих комплексов. Результать демонстрируют возможности детального плотностного моделирования для изучения строения геологических комплексов фундамента. На основе созданной детальной модели рассмотрены возможные пространственные взаимоотношения главных структурно-вещественных комплексов верхней коры изучаемого района.
\end{abstract}

Ключевые слова: Воронежский кристаллический массив, Елеикий участок, плотностное моделирование, строение земной коры, геологическая модель.

\section{THE CONSTRUCTION OF THE UPPER CRUST OF THE YELETSKIY SECTION OF LOSEVSKIY TERRANE (VORONEZH CRYSTALLINE MASSIF) ACCORDING TO THE DENSITY MODELING DATA}

\begin{abstract}
: the paper considers the methods and results of geophysical study of the upper crust structures for the Yeletskiy site (northeast of the Voronezh crystal massif) on the basis of a complex of geological and geophysical data. The detailed 3D density model was built on the basis of an inversion of local gravitational field anomalies to the anomaly density values of the regional density lithosphere model of the East European Platform. The inversion procedure used data on the density of crystalline basement rocks and estimates of the thickness of these complexes. The results of the simulation demonstrate the possibilities of detailed density modeling to study the structure of geological complexes of the foundation. On the basis of the detailed model created, the possible spatial relationships of the main structural and rocks complexes of the upper crust of the study area are considered.
\end{abstract}

Key words: Voronezh crystalline massif, Yeletskiy section, density modeling, Earth's crust structure, geological model.

\section{Введение}

Исследование глубинного строения континентальной земной коры представляет одну из ключевых задач геофизики, нацеленную на создание моделей эволюции литосферы. Для Воронежского кристаллического массива (ВКМ), перекрытого относительно мощным осадочным чехлом, в последние два десятилетия предложен ряд региональных геолого-текто- нических схем [1-4], в разной мере базирующихся на данных геофизических методов. На уровне более детальных построений, ориентированных на создание моделей верхней коры ВКМ, необходимо использовать весь арсенал современных методов интерпретации геофизических данных, позволяющих создавать содержательные геологические модели изучаемой среды. 
В работе рассматриваются результаты плотностного моделирования строения верхней части земной коры в районе углового сочленения архейского Курского блока и протерозойского Лосевского террейна ВКМ (рис. 1). Для этой области, весьма слабо изученной бурением, существует необходимость создания трёхмерной модели верхней коры, поскольку ранее представленные схемы кристаллического фундамента опираются только на анализ морфологии геофизических полей. Создание трёхмерной модели коры должно базироваться на всей совокупности материалов по геологии, петрофизике, геофизическим полям и региональным данным о строении литосферы. Развёрнутое описание материалов и подходы к их интерпретации рассматриваются далее в соответствующих разделах работы. Совокупность представленных результатов моделирования даёт существенное уточнение структуры верхней коры района исследований и позволяет с новых позиций взглянуть на эволюцию зоны сочленения Курского блока и Лосевского террейна ВКМ в раннем протерозое.

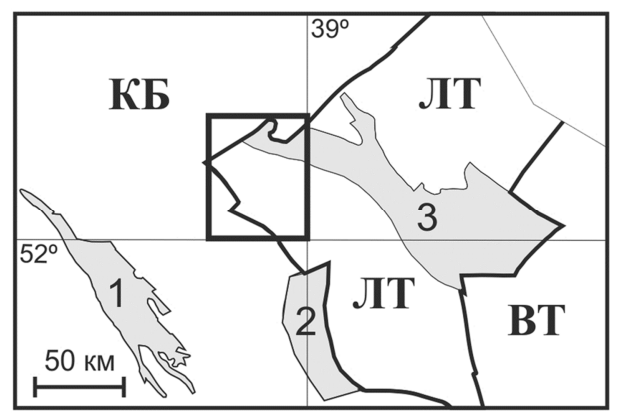

Puc. 1. Схематическая структурная карта северовосточного фрагмента ВКМ по [5] с дополнениями. Показано положение результативного участка плотностного моделирования. Аббревиатуры структур первого порядка: $К Б$ Курский блок (AR); ЛT - Лосевский террейн $\left(\mathrm{PR}_{1}\right) ; B T-\mathrm{Bo}-$ ронцовский террейн $\left(\mathrm{PR}_{1}\right)$. Структуры второго порядка: 1 Тим-Ястребовская $\left(\mathrm{PR}_{1}\right) ; 2$ - Павловский комплекс $\left(\mathrm{PR}_{1}\right) ; 3$ Байгоровская $\left(\mathrm{PR}_{1}\right)$.

\section{Исходные данные}

Геология района. Изучаемая территория (рис. 1) находится на сочленении Курского блока и Лосевского террейна, характеризующихся своеобразием слагающих их структурно-вещественных комплексов (СВК) и истории геологического развития.

Курский блок на территории исследований (рис. 2) представлен породами нижнего и верхнего архея [1]. Он отделён от Лосевского террейна Ряжско-Кантемировским глубинным разломом. В Курском блоке выделяются два структурных яруса. Нижнеархейский структурный ярус представлен СВК этапа консолидации коры. К этому ярусу отнесены метаморфические образования нижнеархейского возраста (обоянский плутоно-метаморфический комплекс). На докембрийской поверхности они слагают обширные территории, выступающие как антиклинорные поднятия среди нижнепротерозойских образований. Наиболее ранни- ми из них являются комплексы мигматитов и плагиогнейсов. Контакт с верхним структурным ярусом тектонический. Верхнеархейский структурный ярус представлен СВК коллизионного этапа [1, 4]. Образования яруса развиты ограниченно и представлены гранитоидами завершающих стадий формирования гранит-зеленокаменных областей - салтыковский плагиогранитный комплекс и атаманский комплекс умеренно-щелочных гранитов.

Лосевский террейн сложен породами верхнего архея и нижнего протерозоя [5]. Можно выделить два структурных яруса: позднеархейский-раннекарельский структурный ярус, представленный СВК этапа формирования активной окраины, и позднекарельский структурный ярус СВК коллизионного этапа. Позднеархейский-раннекарельский структурный ярус сложен метаморфизованными осадочно-вулканогенными (лосевская серия), плутоническими образованиями (рождественский комплекс) и гранитоидами завершающих стадий формирования яруса (усманский мигматит-плагиогранитовый комплекс). В целом в состав комплекса входят образования, характеризующие формирование островной дуги (нижняя часть лосевской серии и рождественский комплекс) и формирование активной континентальной окраины (верхняя часть лосевской серии и усманский мигматит-плагиогранитовый комплекс). Позднекарельский структурный ярус сложен образованиями мигматитгранит-граносиенитового состава (павловский комплекс), вулканогенно-осадочными породами (воронежская свита) и гранит-габброноритами (ольховский комплекс). Гранитоиды комплекса секут и мигматизируют породы ЛТ. Верхняя граница яруса хорошо определяется, так как на позднеархейские-нижнекарельские толщи после длительного перерыва с резким структурным несогласием залегают породы позднекарельского возраста (воронежская свита).

Региональная модель. Региональная плотностная модель литосферы центральной части ВосточноЕвропейской платформы (ВЕП) [6-8], включающая территорию ВКМ, является необходимой основой для создания детальных моделей верхней коры. Технология создания такой модели, подробно изложенная в публикациях авторов, подразумевает, что региональная модель учитывает все особенности сейсмоскоростной и термической моделей коры и верхней мантии изучаемого региона. Построенная в результате решения региональной обратной задачи гравиметрии трёхмерная плотностная модель литосферы центральной части ВЕП [6-8] при детальном моделировании выступает как модель, относительно которой отсчитываются избыточные плотности верхней коры, а гравитационное поле этой модели является уровнем отсчёта для локальных гравитационных аномалий, подлежащих инверсии при детальном моделировании. Отметим, что локальные аномалии поля избавлены от влияния осадочного чехла [9], поскольку гравитационное поле последнего было с максимальной детальностью учтено для всего региона исследований. 


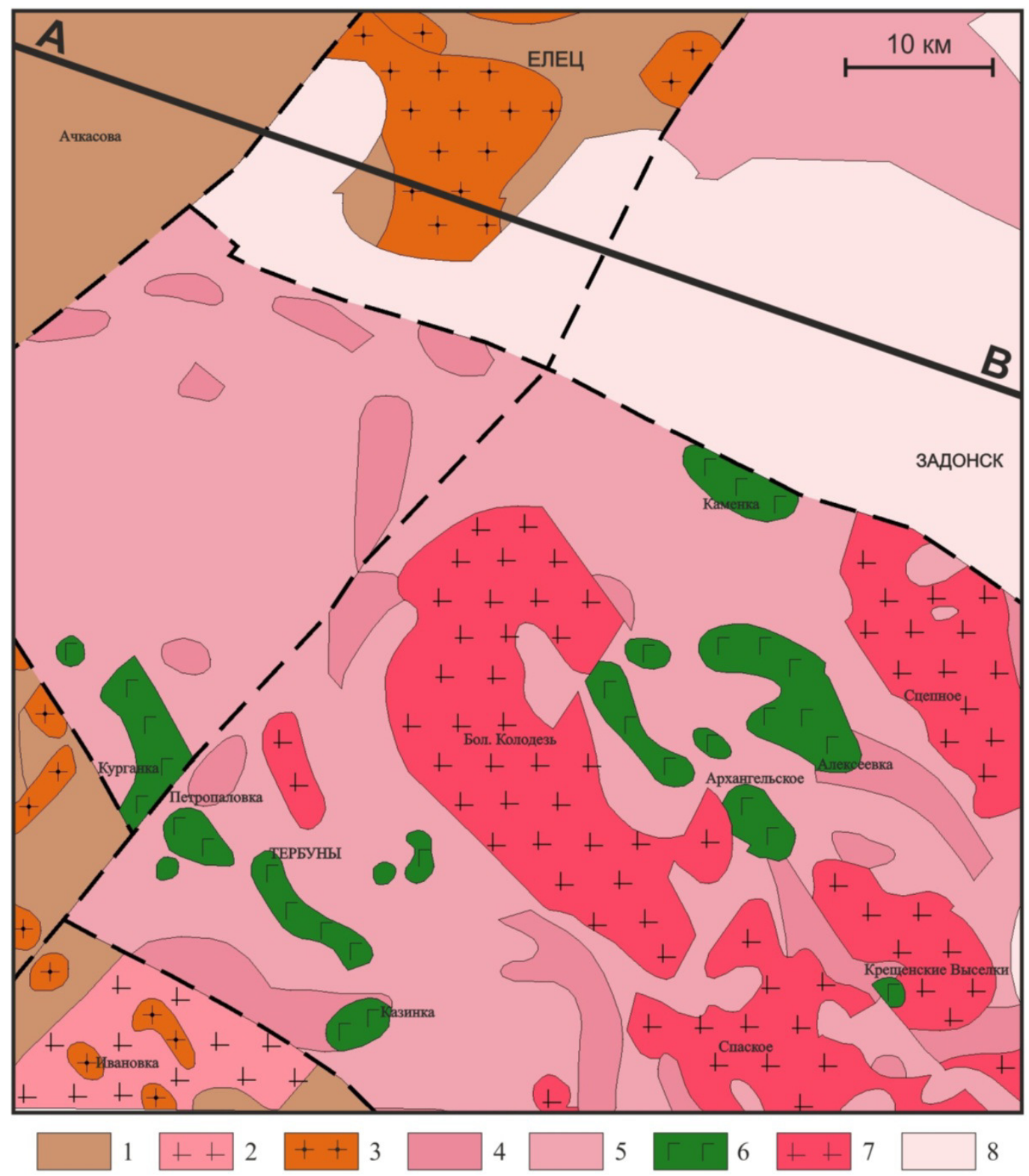

Puc. 2. Схематическая геологическая карта листа N-37-XXXIII. Показано положение разреза плотностной модели. Условные обозначения: 1 - плагиогнейсы биотитовые, гранат-биотитовые, биотит-амфиболитовые, амфиболитовые, интенсивно мигматизированные $\left(\mathrm{AR}_{1} o b\right) ; 2$ - плагиограниты $\left(\mathrm{AR}_{2} s l\right) ; 3$ - граниты субщелочные, биотитовые, биотит-амфиболовые $\left(\mathrm{AR}_{2} a\right) ; 4$ метабазальты, метаандезиты ( $\left.\mathrm{AR}_{2}: \mathrm{PR}_{1} l s_{1}\right) ; 5$ - метадациты, метариолиты, метабазальты, метатуфы, сланцы, металевролиты, метапесчаники $\left(\mathrm{AR}_{2}: \mathrm{PR}_{1} l s_{2}\right) ; 6$ - габбро, габбронориты $\left(\mathrm{PR}_{1} r\right) ; 7$ - плагиограниты биотитовые, роговообманково-биотитовые $\left(\mathrm{PR}_{1} u\right) ; 8$ - метаандезиты, метаандезито-базальты, метатуфы, метатуфопесчаники $\left(\mathrm{PR}_{1} v r\right)$.

Петроплотностная модель. Для пород кристаллического фундамента ВКМ создана петроплотностная карта [10-12], базирующаяся на результатах петрофизических измерений пород керна скважин вскрывших фундамент. Интегрированные данные о плотности и магнитных свойствах, привязанные к соответствующим комплексам кристаллических пород, позволяют оперировать средними значениями физических параметров и диапазоном изменений этих параметров, что является одним из ведущих принципов построения реалистичных решений обратной задачи в нашей постановке $[13,14]$. Еще одним важным моментом в решении обратной задачи для области верхней коры региона является априорная стохастическая оценка глубинного положения источников гравитационного поля, которая была получена по корреляционным функциям поля [15] и послужила некоторым ограничением для начального приближения петроплотностной модели фундамента.

Аномалии поля. Исходными данными для процедуры плотностного моделирования послужило поле локальных гравитационных аномалий $\Delta g_{L}$, определяемое как разность наблюдённого $\Delta g_{0}$ и регионального поля $\Delta g_{R}$ от плотностной модели литосферы [6-8], интерполированного в узлы детальной пространственной сетки вычислений. Поле $\Delta g_{L}$ определено как 


$$
\Delta g_{L}(x, y, h)=\Delta g_{0}(x, y, h)-\Delta g_{R}(x, y, h),
$$

где $h=h(x, y)-$ рельеф дневной поверхности в точках расчёта полей. В таком представлении локальных аномалий, процедура инверсии поля $\Delta g_{L}$ даёт значения искомой избыточной плотности $\Delta \sigma_{L}(x, y, z)$ относительно абсолютной плотности региональной модели литосферы $\sigma_{R}(x, y, z)$.

\section{Метод инверсии}

Расчёт локальных плотностных неоднородностей $\Delta \sigma_{L}(x, y, z)$ выполнялся на основе решения линейной обратной задачи гравиметрии $[13,16]$ в форме:

$$
\left\|\Delta g_{L}(x, y, h)-\mathbf{A}_{H}\left\{\Delta \sigma_{L}(x, y, z)\right\}\right\|<\varepsilon,
$$

где $\mathbf{A}_{H}$ - оператор прямой задачи (для слоя с глубиной нижней границы равной $H$ ) и $\varepsilon$ - требуемая точность решения. Формулировка (2) дополнена условием минимизации функционала качества решения, построенного на параметрах среды:

$$
\left\|W(x, y, z) \times \Delta \sigma_{L}(x, y, z)\right\|=\min ,
$$

где $W(x, y, z)$ - весовая функция перераспределения плотности. Эта функция, выступающая как мера неопределённости наших представлений о начальной модели среды, формируется исходя из естественных соображений: 1) плотностные неоднородности, формирующие поле $\Delta g_{L}(x, y, h)$, сосредоточены в слое, ограниченном сверху поверхностью кристаллического фундамента, а снизу заданной постоянной глубиной $H ; 2)$ высоко-градиентные локальные аномалии $\Delta g_{L}(x, y, h)$, с размерами один-два шага сетки в плане, обусловлены только приповерхностными плотностными неоднородностями; 3) оценка мощности гравиактивного слоя коры [15] позволяет утверждать, что горизонтальный градиент плотностных неоднородностей существенно уменьшается ниже глубины подошвы гравиактивного слоя.

Таким образом, обратная задача для поля $\Delta g_{L}(x, y, h)$ состоит из инверсии высокоградиентных аномалий и инверсии всего остального локального поля. В первом случае функция $W(x, y, z)$ имеет максимум на кровле кристаллического фундамента и очень быстро убывает с глубиной. Во втором - функция $W(x, y, z)$ плавно достигает максимума на глубине подошвы гравиактивного слоя коры и далее плавно убывает до глубины $H$. Существенным моментом в решении задачи (2)-(3) является использование ограничений на искомую плотность:

$$
\Delta \sigma_{\mathrm{MIN}}(x, y, z)<\Delta \sigma_{L}(x, y, z)<\Delta \sigma_{\mathrm{MAX}}(x, y, z),
$$

где минимальное и максимальное значения плотности задаются для всей области решения на основании данных [11]. Наличие таких ограничений позволяет получать геологически содержательные результаты моделирования.

Собственно технология расчётов аномальной плотности в постановке (2)-(4), основанная на аппроксимационном представлении приближенного оператора обратной задачи в спектральной форме [17], была реализована в виде итерационного процесса. Эффективность предлагаемого подхода, продемонстрированная на примерах плотностного моделирования для различных регионов [18-21], в нашем случае позволила создать объёмную модель верхней коры Елецкого участка ВКМ [22].

\section{Результаты}

Расчёты трёхмерной плотностной модели участка исследований выполнялись для регулярной в плане сетки $2 \times 2$ км и дискретного набора уровней по глубине: $0 ; 0,1 ; 0,2 ; 0,4 ; 0,7 ; 1,0 ; 1,5 ; 2 ; 3 ; 4 ; 5 ; 6 ; 8 ; 10$; 12 и 16 км. Принятая сеть вычислений позволяет достаточно точно описать особенности плотностного строения, как самой верхней части разреза $[11,12]$, так и более глубокие уровни коры, отражаемые в региональной модели [6-8]. Поле локальных гравитационных аномалий задавалось на реальном рельефе и в плане охватывало область большую, чем область результативной модели (см. рис. 1). На первой стадии решения вычислялось поле невязки начального приближения от нашей модели, в качестве которой бралась исходная петроплотностная схема фундамента $[11,12]$, транслируемая вертикально до подошвы гравиактивного слоя [15]. Диапазон изменений невязки составляет почти 50 мГал, что свидетельствует о существенном отличии гравитационного поля исходной модели от реального поля на участке работ. Далее для полученного поля невязки начального приближения выполнялось итерационное решение обратной задачи в постановке (2)-(4). Сходимость итерационного процесса обеспечивает итоговую точность решения $\varepsilon= \pm 0,48$ мГал с диапазоном вариаций невязки менее 3 мГал. Такая величина $\varepsilon$ соответствует точности расчёта плотности в изучаемой среде в пределах примерно от $\pm 15 \mathrm{\kappa} / \mathrm{M}^{3}$ (для верхних уровней модели) до $\pm 25 \mathrm{\kappa г} / \mathrm{m}^{3}$ (для нижних уровней). Результаты расчёта локальных трёхмерных плотностных неоднородностей среды подвергались незначительному сглаживанию, для устранения слабых биений в решении, и приводились к абсолютным значениям, с учётом плотности региональной модели [6-8].

Рассчитанная плотностная модель верхней коры, показанная на рис. 3 для нескольких уровней глубин, позволяет обратиться к содержательной геологической трактовке результатов. Приведённая модель демонстрирует значения плотностей, которые могут быть сопоставлены с породными комплексами, опираясь на петроплотностные данные $[11,12]$ и схему геологического строения фундамента (рис. 2). Сводная характеристика пород, приведённая в таблице, даёт возможность отождествления наиболее выразительных плотностных неоднородностей модели с конкретными геологическими образованиями и создания прогнозных схем геологического строения для всего набора глубинных срезов. 

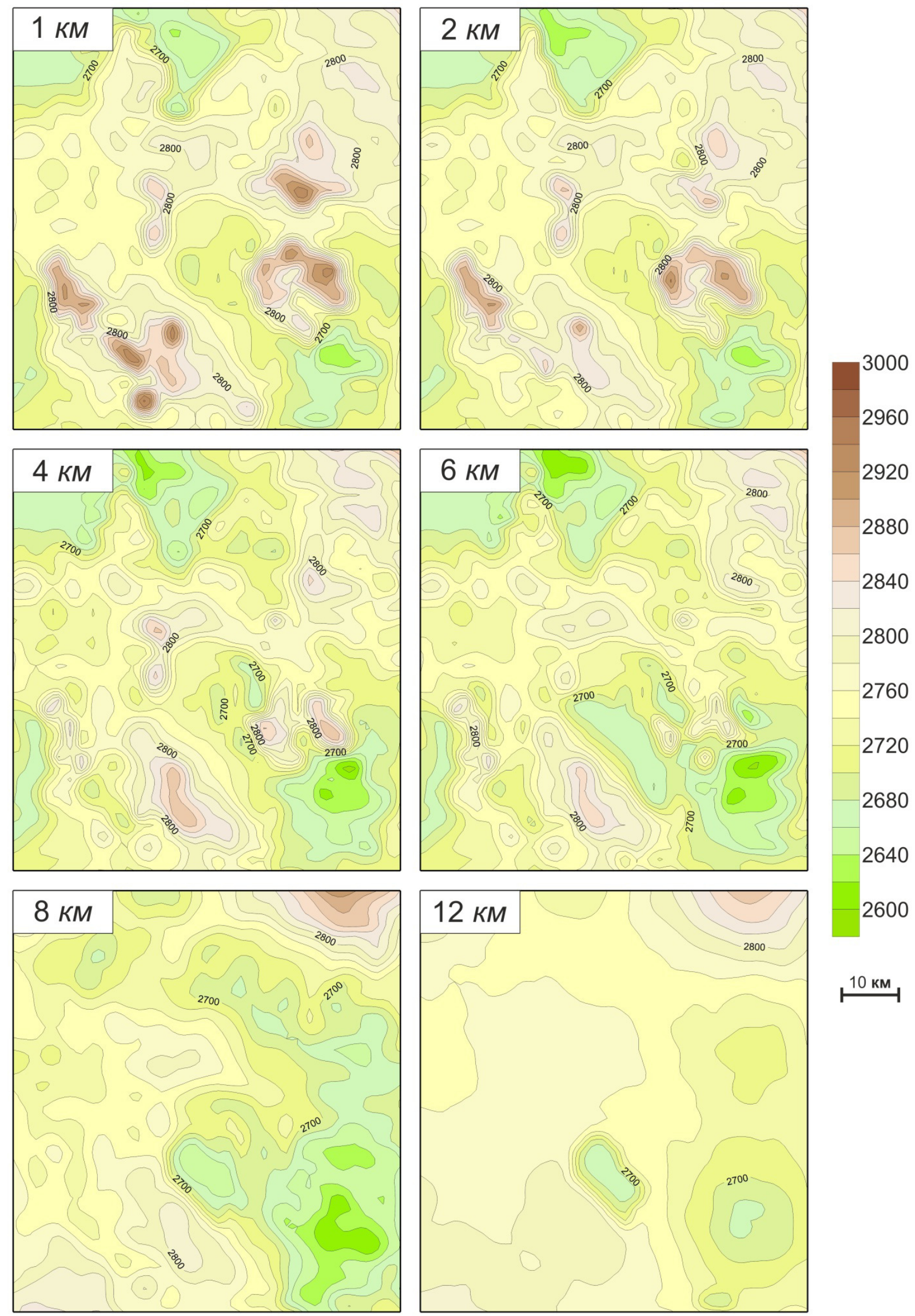

Рис. 3. Плотность в верхней коре на уровнях глубин. 
Строение верхней коры Елеикого участка Лосевского террейна (Воронежский кристаллический массив) ...

Таблица

Петроплотностная характеристика пород

\begin{tabular}{|c|c|c|c|}
\hline \multirow{2}{*}{ Комплексы пород } & \multicolumn{3}{|c|}{ Плотность, кг $/ \mathrm{M}^{3}$} \\
\hline & Mode & Min & Max \\
\hline $\begin{array}{l}\text { Метаандезитобазальты, } \\
\text { метатуфы }\end{array}$ & 2830 & 2670 & 2970 \\
\hline Граниты, плагиограниты & 2680 & 2640 & 2760 \\
\hline Габброиды & 2960 & 2880 & 3180 \\
\hline Диориты & 2740 & 2660 & 2780 \\
\hline Метабазальты, туфы, сланцы & 2770 & 2660 & 2880 \\
\hline Граниты субщелочные & 2640 & 2580 & 2770 \\
\hline Плагиограниты & 2650 & 2620 & 2720 \\
\hline Мигматиты & 2680 & 2630 & 2750 \\
\hline Гнейсы, кристаллосланцы & 2710 & 2650 & 2870 \\
\hline
\end{tabular}

\section{Анализ результатов}

Основой для геологической трактовки результатов плотностного моделирования послужила сводная геологическая карта ВКМ масштаба 1:500 000 (по материалам С. П. Молоткова и др., 1999), фрагмент которой представлен на рис. 2. Картирование фундамента в пределах всей площади карты базировалось на результатах гравимагнитных съёмок и, частично, поддержано бурением. На участке исследований фундамент вскрыт лишь шестью скважинами, сосредоточенными в юго-западной части территории в области развития пород рождественского комплекca. Очевидно, что в таких условиях геологическое картирование по геофизическим полям носило сугубо прогнозный характер и нуждается в существенном уточнении на основе рассчитанной трёхмерной плотностной модели, которая позволяет транслировать на глубинные горизонты поверхностные геологические неоднородности.
Тектонические структуры

Для основных тектонических элементов изучаемой территории интерес представляет характер положения западной границы ЛТ на глубине (рис. 1). В пределах рассматриваемой площади тектоническая граница между структурами Курского блока и Лосевского террейна представлена двумя фрагментами Ряжско-Кантемировского разлома - юго-западным и северо-западным. Они чётко отражены в плотностных срезах модели до глубины примерно 1,5 км (рис. 3). Здесь плоскость, аппроксимирующая положение границы структур КБ и ЛТ - субвертикальна, что согласуется с данными [23]. По мере погружения граница приобретает отчётливо выраженное юговосточное падение, показанное на вертикальном плотностном разрезе модели (рис. 4). Эта тенденция сохраняется на уровне 6 км, а на уровне 8 км угол падения становится более пологим, причём градиент наклона, даже в пределах одного и того же северозападного фрагмента разлома, имеющего протяжённость порядка 50 км, существенно различен (рис. 3). Начиная с глубины 10 км угол падения границы выполаживается, и на уровне 12 км становится субгоризонтальным (рис. 4). Созданная модель показывает, что в пределах рассматриваемой площади мощность протерозойских отложений ЛТ, перекрывающих архейское основание, достигает максимальных значений на глубинах 10-12 км на удалении нескольких десятков километров к юго-востоку от планового положения контакта этих структур на поверхности кристаллического фундамента (рис. 3,4 ). Таким образом, результаты плотностного моделирования подтверждают концепции формирования ЛТ, как крупной коллизионной структуры на границе блоков литосферы $[2,3,24]$.

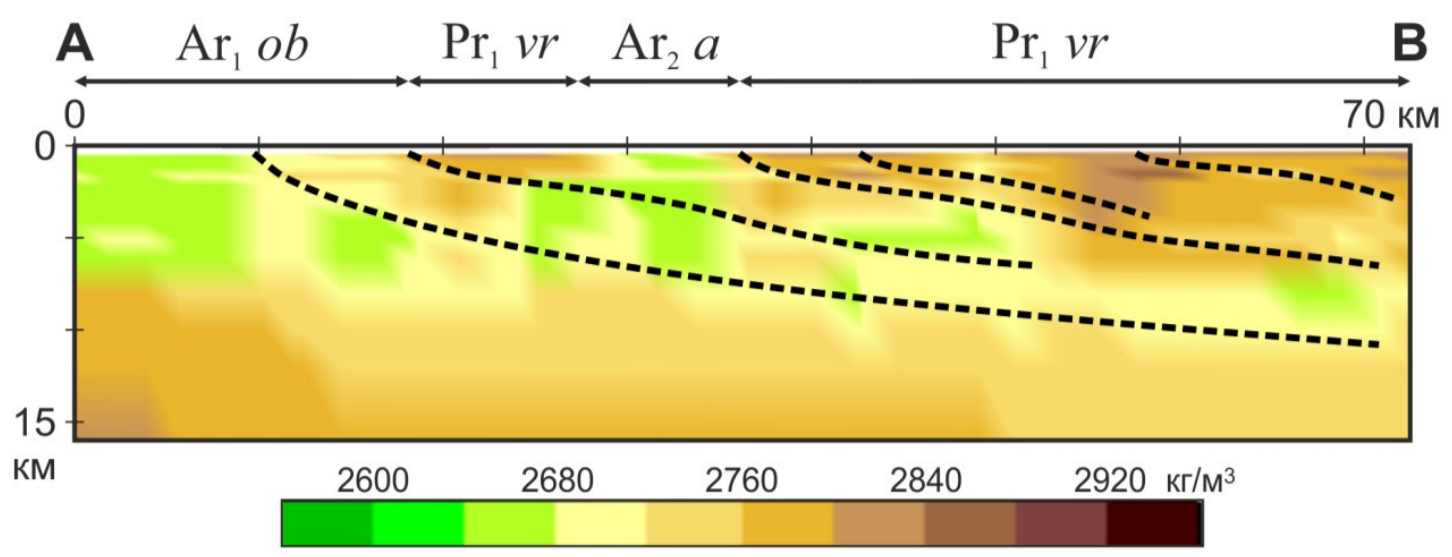

Puc. 4. Плотностной разрез по линии АВ (см. рис. 2). Показаны предполагаемые тектонические нарушения и структурные границы.

В рамках рассматриваемой территории Лосевского террейна узкой полосой залегают образования воронежской серии (рис. 2), выполняющие северозападную апофизу т.н. «Байгоровской грабенсинклинальной структуры», сложенной слабометаморфизованными вулканогенными и вулканогенно- осадочными породами. Приповерхностная часть структуры контрастно проявлена до глубины 1,5 км (рис. 3) по характеру изоденс повышенных значений

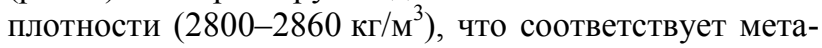
вулканитам (табл.). Далее вниз по разрезу плотность несколько убывает (рис. 4), достигая на уровне 5 км 
значений менее 2700 кг $/ \mathrm{m}^{3}$, что отвечает гнейсам и кристаллическим сланцам (табл.). Существенные изменения в морфологии и амплитудах поля изоденс происходят на глубинах 6-10 км, где в рамках грабенсинклинали породы пониженной плотности (2640$\left.2720 \mathrm{\kappa г} / \mathrm{M}^{3}\right)$ закономерно погружаются в восточном направлении (рис. 4). Геологическая трактовка установленного распределения плотности может отвечать следующей эволюционной модели: структура была заложена на блоковом гранито-гнейсовом основании и имеет относительно глубокие «корни», на уровне которых (ниже 6 км) породы существенно метаморфизованы, о чем свидетельствует их низкая плотность. В интервале глубин примерно 1-6 км породы грабен-синклинали, предположительно сложены метаморфизованными осадочно-вулканогенными образованиями лосевской серии, на которых и закладывалась Байгоровская структура. Породы воронежской свиты, выполняющие синклиналь, фиксируются на изученном фрагменте в приповерхностном уровне до 500-700 м. Здесь, судя по характеру распределения плотности, вещественный состав воронежской свиты существенно изменяется - от преобладания в разрезе более плотных метаандезитобазальтов (юго-восточная часть) до метаморфизованных туфов и песчаников с более низкой плотностью (северо-западная часть).

\section{Интрузивнье образования}

Магматиты кислого и основного состава достаточно контрастны по плотности (табл.) и поэтому хорошо проявляются в результатах моделирования в случае, когда их размеры превышают в плане размер ячейки сети расчётов ( $2 \times 2$ км). На самых верхних уровнях модели положение плотностных аномалий интрузивных образований в основном совпадает с конкретными комплексами пород, представленными на исходной карте (рис. 2). Пример сопоставления геологической карты фундамента с прогнозной схемой контрастных по плотности интрузивных комплексов на глубинном срезе 0,4 км, показан на рис. 5 . Отрисовка положения предполагаемых интрузивных объектов кислого и основного состава выполнялась по схемам изоденс, для соответствующего глубинного среза, основываясь на данных о плотности комплексов пород (табл.).

Как явствует из приведённого сопоставления, ряд интрузивных объектов, показанных на геологической карте фундамента, имеет существенно меньшие размеры в нашей плотностной модели. Особо это касается крупного тела кислых вулканитов в центральной части площади исследований, условно названного нами Дубровским массивом. Второй аналогичный массив, условно названный Муравьевским, в плотностной модели на уровне фундамента представляет единое тело, а не два отдельных массива, как это показано на геологической карте (рис. 5 a). Такое несоответствие, вероятно, обусловлено тем, что эти массивы, относящиеся к мигматит-плагиогранитному усманскому комплексу, характеризуются зональным строением [23] с уменьшением содержания плагиоклаза и биотита, исчезновением роговой обманки и возрастанием содержания микроклина в гранитах от периферии к центральной (жерловой?) части массивов. То есть на верхних уровнях модели (см. рис. 3) плотностная дифференциация усманских гранитоидов и вмещающих пород лосевской серии будет не столь выразительной для чёткого выделения границ массивов по горизонтальному градиенту плотности (рис. 6).

На более глубоких уровнях, начиная с 3 км, для Дубровского массива наблюдается смещение минимумов плотности в восточном направлении (рис. 3), где массив уменьшается в размерах и приобретает выраженную линейную форму с субмеридиональным простиранием (рис. 6). Область низких значений плотности с глубиной локализуется и на уровне 12 км (рис. 3), где Дубровский массив представляет собой линейное тело с поперечными размерами примерно 7х15 км (рис. 6). Для Муравьевского массива с глубиной характерно лишь незначительное уменьшение размеров с сохранением изометричной формы тела (рис. 6). Радикальное уменьшение размеров массива начинается с глубины 8 км, и на уровне 12 км массив представляет изометричное тело с поперечными размерами примерно 10 км (рис. 6). Обращает на себя внимание абсолютная величина и горизонтальный градиент плотности (рис. 3) на границах корневых частей Дубровского и Муравьевского массивов (рис. 6). Такой характер плотности позволяет утверждать, что породы, слагающие абиссальную часть крупных гранитоидных массивов усманского комплекса, являются существенно микроклиновыми. По морфологии и пространственной ориентировке корневых частей массивов можно предполагать, что они формировались в несколько различных тектонических условиях.

Рассмотрим ещё один гранитоидный массив, расположенный в северной части участка и сложенный субщелочными гранитами атаманского комплекса позднеархейского возраста. На уровне фундамента его положение хорошо совпадает с геологическими построениями (рис. 5), а по значениям плотности пород (рис. 3) массив чётко отождествляется с субщелочными гранитами (табл.). На глубине свыше 3 км устанавливается общее смещение положения массива на северо-запад с уменьшением его размеров (рис. 6). Эта тенденция сохраняется вплоть до глубины 6 км, ниже которой тело массива выходит за пределы рассматриваемой территории моделирования.

Что касается пород основного состава, то они также находят свое отражение в нашей модели как пространственно компактные области повышенной плотности (рис. 3), приуроченные к области развития вулканогенно-осадочных образований лосевской серии (рис. 2). Здесь небольшие по размерам интрузивные тела габброидов рождественского комплекса формируют два ареала в юго-западной и юго-восточной частях участка (рис. 5). В приповерхностном слое (рис. 6) интрузивные тела фиксируются значениями 

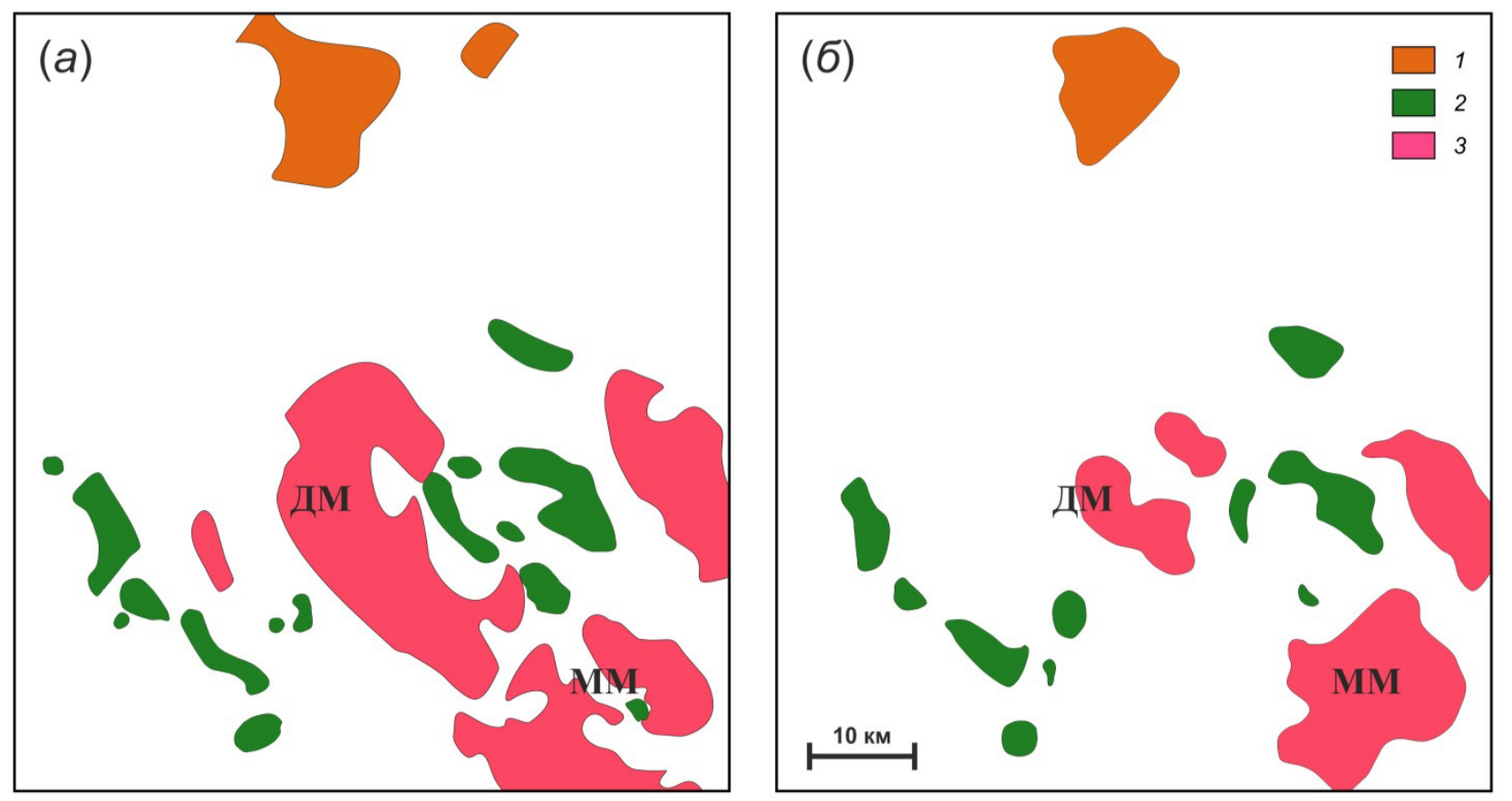

Puc. 5. Положение интрузивных комплексов на поверхности кристаллического фундамента по геологическим данным (a) и по данным плотностного моделирования (б). Аббревиатуры: ДМ - Дубровским массив; ММ - Муравьевский массив. Условные обозначения: 1 - субщелочные граниты $\left(\mathrm{AR}_{2} a\right) ; 2$ - габброиды $\left(\mathrm{PR}_{1} r\right) ; 3$ - плагиограниты биотитовые $\left(\mathrm{PR}_{1} u\right)$.
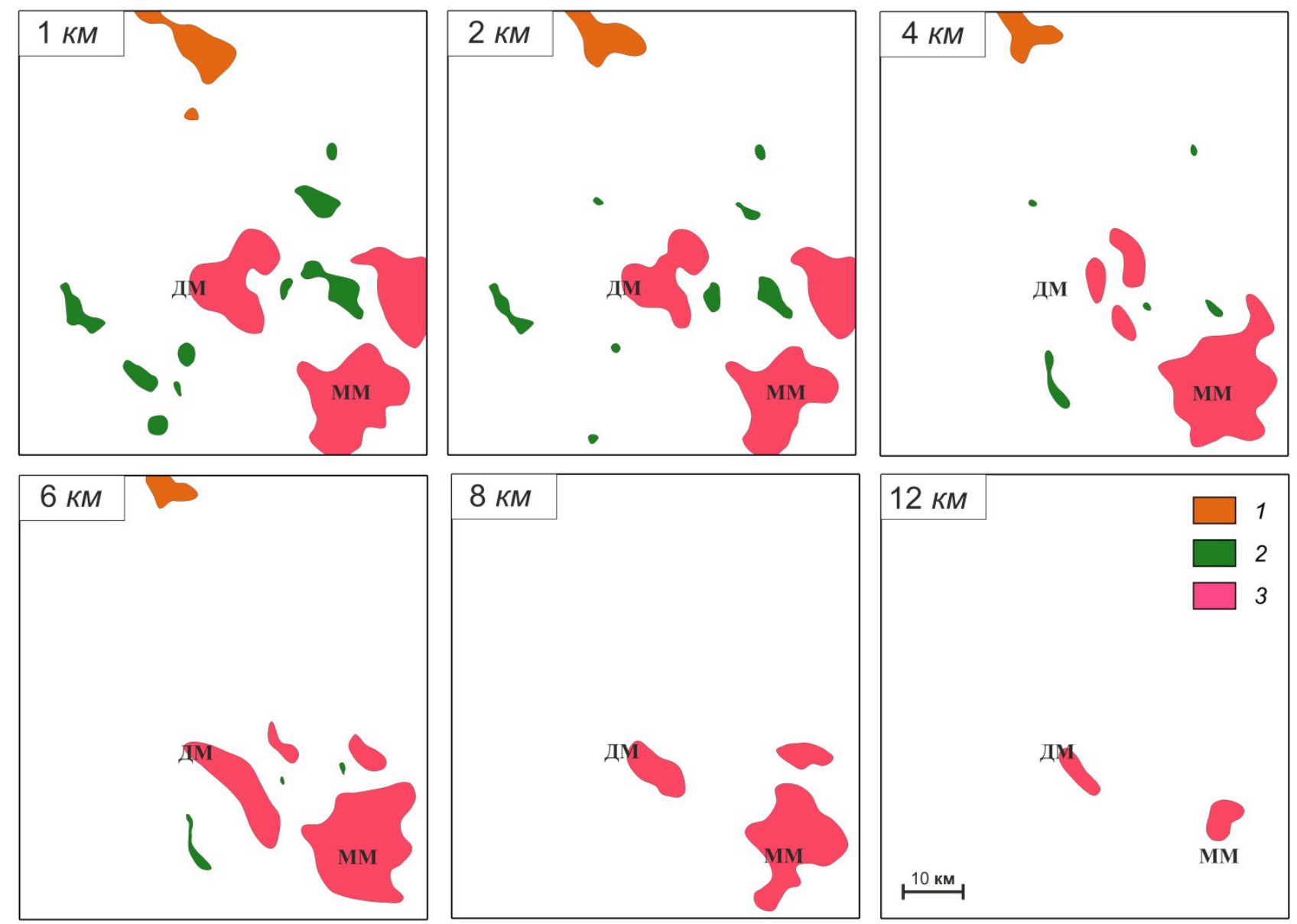

Puc. 6. Положение интрузивных комплексов на уровнях глубин в верхней коре. Условные обозначения см. рис. 5. 
плотности, порой превышающими 3000 кг $/ \mathrm{M}^{3}$ (рис. 3). До глубины 2 км контуры массивов меняются незначительно и только с уровня 4 км намечаются изменения конфигурации и характера распределения объектов в пределах обоих ареалов (рис. 6). В частности, для юго-западного ареала характерна линейная субмеридиональная локализация корневой части южной группы массивов этого ареала, сохраняющаяся до глубины 6-8 км, что позволяет говорить о трещинном типе подводящего канала. Иная картина наблюдается для юго-восточной группы интрузий. Здесь размеры интрузивных тел габброидов с глубиной уменьшаются и приобретают более изометричную форму, а некоторые массивы уже практически не прослеживаются на глубине более 3-4 км (рис. 6). Выявленные признаки пространственной ориентировки корневых частей габброидов рождественского комплекса позволяют предполагать некоторые различия тектонических обстановок формирования массивов.

\section{Заключение}

Развиваемая авторами технология трёхмерного плотностного моделирования, основанная на аппроксимационном представлении оператора обратной задачи для горизонтального слоя [17] и использующая совокупность информации о геологии кристаллического фундамента ВКМ (по данным С.П. Молоткова и др., 1999), региональной плотностной модели литосферы $[6-8,15]$ и петроплотностных данных для пород фундамента [10-12], позволила рассчитать максимально достоверную плотностную модель верхней коры Елецкого участка Лосевского террейна [22]. Анализ созданной трёхмерной модели, реализующей трассирование на глубину дифференцированных по плотности поверхностных геологических комплексов кристаллического фундамента, выявил основные геолого-тектонические особенности строения верхней коры на участке исследования:

1. Установлено пространственное положение тектонической границы между Курским блоком и Лосевским террейном, отвечающей современной концепции формирования последнего, как крупной коллизионной структуры протерозойской литосферы [2, 3, 24].

2. Предложена возможная модель строения северозападного апофиза Байгоровской структуры, заложенной на гранито-гнейсовом основании и имеющей относительно глубокие «корни». В пределах структуры установлена пространственная плотностная зональность пород воронежской свиты, выполняющей приповерхностный ярус структуры.

3. Сформированы реалистичные модели пространственного положения интрузивных массивов кислого и основного состава, приуроченных к области развития вулканогенно-осадочных образований лосевской серии. Выявлены характерные ориентировки их корневых частей, свидетельствующие о специфике тектонических обстановок формирования массивов.
Авторы выражают благодарность проф. А. С. Долгалю за полезное обсуждение методики и результатов плотностного моделирования.

Исследование выполнено в рамках гранта РФФИ № 19-05-00336.

\section{ЛИТЕРАТУРА}

1. Геодинамическая модель формирования Воронежского кристаллического массива / Н. М. Чернышов [и др.] // Геотектоника. - 1997. - № 3. - С. 21-31.

2. Глубинное строение, эволюция и полезные ископаемые раннедокембрийского фундамента Восточно-Европейской платформы: Интерпретация материалов по опорному профилю 1-ЕВ, профилям 4В и Татсейс в 2 т. / М. В. Минц [и др.]. - М.: ГЕОКАРТ; ГЕОС, 2010. - Т. 1. - 408 с.; Т. 2. $400 \mathrm{c}$.

3. Мини, М. В. Строение и эволюция средне-палеопротерозойского Брянск-Курск-Воронежского внутриконтинентального коллизионного орогена (Восточно-Европейский кратон) / М. В. Минц, В. А. Буш, С. Н. Агеев // Геодинамика и тектонофизика. - 2014. - V. 5. - № 3. - Р. 717-742.

4. Мегаблок Сарматия как осколок суперкратона Ваалбара: корреляция геологических событий на границе архея и палеопротерозоя / К. А. Савко [и др.] // Стратиграфия. Геологическая корреляция. - 2017. - Т. 25. - № 2. - С. 3-26.

5. Терентьев, Р. А. Геология, вещественный состав и палеогеодинамические условия формирования Лосевской серии (Воронежский кристаллический массив) / Серия геология докембрия ВКМ. Вып. 1. - Воронеж, 2013. - 222 с.

6. Муравина, О. М. Плотностная модель земной коры Воронежского кристаллического массива / О. М. Муравина // Вестник Воронеж. гос. ун-та. Сер.: Геология. - 2016. - № 1. - C. 108-114.

7. Глазнев, В. Н. Плотностное моделирование земной коры центральной части Восточно-Европейской платформы / В. Н. Глазнев, М. В. Минц, О. М. Муравина // Вестник КРАУНЦ. Сер.: Науки о Земле. - 2016. - № 1 (29). - С. 53-63.

8. Мини, М. В. Глубинное строение коры юго-востока Воронежского кристаллического массива по геофизическим данным: геодинамическая эволюция в палеопротерозое и современное состояние коры / М. В. Минц, В. Н. Глазнев, О. М. Муравина // Вестник Воронеж. гос. ун-та. Сер.: Геология. - 2017. - № 4. - С. 2-23.

9. Муравина, О. М. Петрофизическая характеристика осадочного чехла Воронежской антеклизы / О. М. Муравина, В. И. Жаворонкин В. Н. Глазнев // Вестник Воронеж. гос. ун-та. Сер.: Геология. - 2013. - № 1. - С. 189-196.

10. Муравина, О. М. Пространственный анализ распределения плотности докембрийских образований Воронежской кристаллического массива / О. М. Муравина, В.И.Жаворонкин В.Н. Глазнев // Материалы 15-ой международной конференции «Физико-химические и петрофизические исследования в науках о Земле», М.: ИФЗ РАН. - 2014. C. $171-173$.

11. Муравина, О. М. Статистический анализ цифровой основы петроплотностной карты Воронежского кристаллического массива / О. М. Муравина, В. И. Жаворонкин // Вестник Воронеж. гос. ун-та. Сер.: Геология. - 2015. - № 2. C. 94-99.

12. Муравина, О. М. Петроплотностная карта Воронежского кристаллического массива / О. М. Муравина, В. И. Жаворонкин, В. Н. Глазнев // В сборнике: Вопросы теории и практики геологической интерпретации геофизических полей. Материалы 43-й сессии Международного научного 
семинара им. Д. Г. Успенского. Воронеж: «Научная книга». - 2016. - С. 133-136.

13. Глазнев, В. Н. Комплексные геофизические модели литосферы Фенноскандии / В. Н. Глазнев. - Апатиты: Изд. «КаэМ». - 2003. $-252 \mathrm{c}$.

14. Complex geological-geophysical 3D model of the crust in the southeastern Fennoscandian Shield: Nature of density layering of the crust and crust-mantle boundary / V. N. Glaznev [et al.] // Geodynamics \& Tectonophysics. - 2015. - V. 6. - № 2. P. $133-170$.

15. Оценка мощности гравиактивного слоя земной коры Воронежского кристаллического массива / В. Н. Глазнев [и др.] // Вестник Воронеж. гос. ун-та. Сер.: Геология. - 2014. № 4. - C. $78-84$.

16. Страхов, В. Н. Теория линейных обратных гравиметрических задач / В. Н. Страхов // Докл. АН СССР. - 1990. T. 311. - № 5. - C. 1093-1096.

17. Трёхмерная модель верхней коры района Киттила Соданкюля, Финская Лапландия (север Балтийского щита) / В. Н. Глазнев [и др.] // Сборник материалов, посвящённый 40-летнему юбилею кафедры геофизики ВГУ. Воронеж: ВГУ. - 2002. - С. 11-20.

18. Morphology and internal structure of the Kola alkaline intrusions, NE Fennoscandian Shield: 3D density modelling and geological implication / A. A. Arzamastsev [et al.] // Journal of Asian Earth Sciences. - 2000. - V. 18. - № 1. - P. 213-228.

ФГБОУ ВО «Воронежский государственный университет» Геологический институт - Обособленное подразделение Федерального государственного бюджетного учреждения науки Федерального исследовательского иентра «Кольский научный центр Российской академии наук» (ГИ КНЦ РАН), 2. Anатить

Глазнев Виктор Николаевич, доктор физикоматематических наук, заведующий кафедрой геофизики ВГУ, главный научный сотрудник Геологического инстиmута КНЦ РАН

E-mail: glaznev@geol.vsu.ru; Тел.: +7 (473) 2208385

ФГБОУ ВО «Воронежский государственный университет»

Жаворонкин Валерий Иванович, кандидат геологоминералогических наук, доиент кафедры геофизики E-mail:vzhavoronkin@yandex.ru; Тел.: +7 (473) 2208385

Муравина Ольга Михайловна, доктор технических наук, профессор кафедры геофизики

E-mail: muravina@geol.vsu.ru; Tел.: +7 (473) 2208385

Антонова Ирина Юрьевна, преподаватель кафедры геофизики

E-mail:mavka_r@mail.ru; Тел.:+7 (473) 2208385

Воронова Татьяна Александровна, кандидат геологоминералогических наук, доцент кафедры геофизики E-mail:voronova28@yandex.ru; Тел.: +7 (473) 2208385

Холин Павел Владимирович, инженер НИИ Геологии ВГУ Тел.: +7 (473) 2207842
19. Расслоенные интрузии Мончегорского рудного района: петрология, оруденение, изотопия, глубинное строение. Часть 2. Ред.: Ф. П. Митрофанов, В. Ф. Смолькин / В. В. Борисова [и др.]. - Апатиты: ГИ КНЦ РАН. - 2004. - 177 с.

20. Глазнев, В. Н. Новые данные о глубинном строении Хибинского и Ловозерского массивов, Кольский полуостров / В. Н. Глазнев, А. М. Жирова, А. Б. Раевский // Докл. РАН. 2008. - T. 422. - № 3. - С. 391-393.

21. Объёмная модель глубинного строения Свекофеннского аккреционного орогена по данным МОВ-ОГТ, МТЗ и плотностного моделирования / М. В. Минц [и др.] // Труды Карельского научного центра РАН. - 2018. - № 2. - С. 34-61.

22. Антонова, И. Ю. Модель строения верхней части коры Елецкого участка по комплексу геолого-геофизических данных / И. Ю. Антонова, В. Н. Глазнев // Вопросы теории и практики геологической интерпретации гравитационных, магнитных и электрических полей: Сб. научных трудов. Вып. 1 (46). - Пермь: ГИ УрО РАН, ПГНИУ. - 2019. C. 36-39.

23. Минерагенические исследования территорий с двухъярусным строением (на примере Воронежского кристаллического массива) / В. М. Ненахов [и др.]. - М.: ГЕОКАРТ; ГЕОС, 2007. $-284 \mathrm{c}$.

24. Геодинамика восточной окраины Сарматии в палеопротерозое / А. А. Щипанский [и др.] // Геотектоника. - 2007. № $1 .-$ C. $43-70$.

Voronezh State University

GI FRC KSC RAS, Apatity

Glaznev V. N., Doctor of Physical and Mathematical Sciences,

Head of the Department of Geophysics, chief researcher

E-mail: glaznev@geol.vsu.ru

Tel.: +7 (473) 2208385

Zhavoronkin V. I., Candidate of Geological and Mineralogical Sciences, Associate professor of the Department of Geophysics E-mail: vzhavoronkin@yandex.ru

Tel.: +7 (473) 2208385

Muravina O. M., Doctor of Technical Sciences, Professor of the Department of Geophysics

E-mail: muravina@geol.vsu.ru

Tel.: +7 (473) 2208385

Antonova I. Yu., Lecturer of the Department of Geophysics

E-mail:mavka_r@mail.ru

Tel.: +7 (473) 2208385

Voronova T. A., Candidate of Geological and Mineralogical Sciences, Associate professor of the Department of Geophysics E-mail:voronova28@yandex.ru

Tel.: +7 (473) 2208385

Holin P. V., engineer of scientific research institute of Geology of the VSU

Tel.: +7 (473) 2207842 